\title{
US Sector Rotation with Five-Factor Fama-French Alphas
}

\author{
Golam Sarwara , \\ Cesario Mateus ${ }^{\mathrm{a}}$, \\ Natasa Todorovic ${ }^{\mathrm{b}^{*}}$ \\ ${ }^{a}$ University of Greenwich, London, UK \\ ${ }^{b}$ The Centre for Asset Management Research, \\ Cass Business School, City University of London, UK
}

\begin{abstract}
In this paper we investigate the risk-adjusted performance of US sector portfolios and sector rotation strategy using the alphas from the Fama-French five factor model. We find that fivefactor model fits better the returns of US sector portfolios than the three factor model, but that significant alphas are still present in all the sectors at some point in time. In the full sample period, $50 \%$ of sectors generate significant five-factor alpha. We test if such alpha signifies a true sector out/underperformance by applying simple long-only and long-short sector rotation strategies. Our long-only sector rotation strategy that buys a sector with a positive five-factor alpha generates four times higher Sharpe ratio than the S\&P500 buy-and-hold. If the strategy is adjusted to switch to the risk-free asset in recessions, the Sharpe ratio achieved is ten-fold that of the buy-and-hold. The long-short strategy fares less well.
\end{abstract}

Key words: Fama-French Five Factor Model, US sectors, Performance, Sector Rotation JEL code: G10, G11, G12

\footnotetext{
*Corresponding author. Tel.: +44 207040 0120. E-mail addresses:g.sarwar@greenwich.ac.uk (Sarwar), c.mateus@greenwich.ac.uk (Mateus), n.todorovic@city.ac.uk (Todorovic).
} 


\section{$1 \quad$ Introduction and Background}

Fama-French (1993) three-factor model (FF3 hereafter) and Carhart (1997) four factor model, have been used as standard pricing models and benchmark models for portfolio performance among both academics and practitioners. Fama and French (2015) five factor model (FF5 hereafter) represents the newest addition to the multi factor models that have been frequently used in empirical research, both in asset pricing and performance evaluation literature. Regardless of the frequent use of the FF3 model, there is evidence to suggest that it cannot completely explain the cross-section of stock returns ${ }^{1}$. Although FF3 model adjusts for outperformance tendency observed in original CAPM, academics question its ability to explain the cross-sectional variation in expected returns particularly related to profitability and investment (as seen in Chen et al., 2011; Aharoni et al., 2013; Novy-Marx, 2013; Walkshäusl and Lobe, 2014; Titman et al., 2004 among others). Motivated by this, Fama and French, (2015) propose five factor model which adds two additional factors, profitability and investment, to the FF3 model. They find that, for portfolios formed on size, book to market $(\mathrm{B} / \mathrm{M})$, profitability, and investment, the five-factor model provides a better fit than their original FF3 model.

In this paper we investigate the risk adjusted performance of US sector/industry portfolios in terms of the new FF5 model. The results from this segment of our research can be of particular interest to investors considering specialist sector funds. We further test whether the FF5 model alphas in the US sector portfolios can be exploited to formulate a profitable and feasible sector rotation strategy. The presence of sector ETFs makes sector investment strategies such as the one proposed in this paper attractive to practitioners and feasible at a reasonable level of transaction costs. The contribution of this paper to the literature is therefore two-fold: first, it adds to performance measurement literature by assessing US sector/industry performance within the new FF5 setting; and second, it adds to scarce sector investing literature with specific focus on a dynamic market-timing strategy - sector rotation. Sector rotation has received comparatively little attention from academics even though sector return predictability is well documented ${ }^{2}$. We base this study on the following notion: if the FF5 alpha of a sector is indeed the true alpha (i.e. an accurate indicator of stock picking skill),

\footnotetext{
1 Some anomalies such as, positive relationship with momentum returns and earnings surprises, negative relationship with financial distress, net stock issues and asset growth, are left unexplained by Fama-French three factor model (see for example, Chen and Zhang, 2010; Fama and French, 2008, 1996; Cooper, Gulen and Schill, 2008; Daniel and Titman, 2006; Campbell, Hilscher and Szilagyi, 2008, etc)

${ }^{2}$ See for instance Beller, Kling and Levinson (1998)
} 
then applying a sector investment strategy based on such alpha should generate higher return. To the best of our knowledge, this is the first study that applies the new Fama and French (2015) five factor model as a benchmark model of sector performance and as a basis for US sector rotation strategy. Last, but not least, this paper aims to highlight the importance of sector/industry analysis for the investment process. Throughout the paper, we draw comparisons between Fama-French three- and five-factor model's suitability for US sector returns and sector rotation strategy.

Let us first look at the existing evidence on sector performance. Most of the performance measurement literature focuses on the mutual funds, specifically long-only equity funds. The number of studies in this area is vast, see for instance Carhart (1997), Daniel (1997), Wermers (2000), Chen et al. (2000), Pástor and Stambaugh (2002) among others for US evidence. In contrast, much less attention in the literature has been given to the performance of the sector/industry investing. Dellva, DeMaskey and Smith (2001) study the timing and selection ability of 35 Fidelity sector mutual funds from the funds' inception till December 1998. The number of positive Jensen's alphas is 24-33 throughout subperiods, with the exception of 1994-1998 where the alphas declined to negative value. Faff (2004) tests the performance of 24 Australian industry portfolios and finds that there is a tendency for mining and resources to produce negative FF3 alpha, whereas industrials tend to produce a positive one. In the US, Kacperczyk, Sialm and Zheng (2005) investigate the performance of industry concentrated mutual funds over the period January 1984 to December 1999. They argue that, fund managers may deviate from the passive market portfolio by having their portfolio with specific industry concentration, and prove that funds that deviate more from the overall market by focusing on particular industries tend to perform better. Dou et al. (2014) study asset allocation in different economic regimes across sectors in the developed countries (North America, UK, Japan, and Europe). They report positive alpha of Energy, HiTech, and Health sectors; and negative alphas of Durable, Telecom, and Manufacturing sectors both in the bull market and the bear market. In this study, we will also address the sector rotation taking into account different market states.

The success of sector rotation strategies was first documented by Sorensen and Burke (1986) and Grauer, Hakansson and Shen (1990). Fidelity Investments pushed sector investing into the mainstream by launching the slate of sector mutual funds referred as the "Select" series during the 1980s. However, the modern era of sector investing began in December 1998 when the first sector exchange-traded funds (ETFs) were introduced to equity investors. 
Based on the Fidelity Select Sector picking as a selection criteria, Sassetti and Tani (2006) use three simple sector rotation techniques, ranking sectors based on the Rate of Change, Alpha, and Relative Strength Indicator. They apply strategy to 41 funds of the Fidelity Select Sector family from January 1998 to September 2003. They find that, a sector rotation based on the alphas appears more stable than the one using the Rate of Change. Their sector rotation strategy continuously outperforms buy-and-hold strategy. Conover et al. (2008) switch sectors according to macroeconomic conditions and find that their sector rotation strategy has infrequent rebalancing and consistent economically significant returns over the 33 year period in their study. Further, Chong and Philips (2015) find that a portfolio of sector ETFs constructed as a response of sectors to economic factors performs well relative to S\&P 500 index. Outperformance of sector rotation strategy is also documented in the study of Baca, Garbe and Weiss (2000); Conover et al. (2005); Shynkevich (2013) and Dou et al. (2014). Sector rotation studies differ, among other things, in indicators used to signal a switch from one sector to another. The signals range from economic indicators, technical indicators (such as relative strength, widely used in technical analysis) and performance indicators such as alpha.

In this study we use ten US Fama-French sector portfolios in the period 1964-2014 and our findings reveal that FF5 is a better model for describing sector returns than the FF3; containing additional information and having higher R-squared. 5FM is also statistically better fitted model and two addition factors (RMW and CMA) significantly increase the log likelihood of the model. We follow the Sassetti and Tani (2006) who find that alpha-based sector rotation provides more robust performance than that based on other indicators. Hence, we develop a long-only and a long-short sector rotation strategy where a signal for switching is the FF5 factor model alpha. If the FF5 alpha for a sector in period $t$ is positive (negative), we will buy (sell) that sector in period $(\mathrm{t}+1)$. Our sector rotation strategies are illustrated on both Fama-French US sector portfolios and the matching S\&P Select Sector SPDR ETFs. In addition, we differentiate between recessions and expansions, and devise additional long-only strategy, which buys a risk-free asset (US 1 month Treasury Bill) if the economy is in recession.

Our long-only sector rotation strategy based on FF5 alphas outperforms the S\&P 500 buyand-hold benchmark strategy by $5.40 \%$ in terms of mean return and generates approximately four times higher Sharpe ratios. When we integrate business cycles into the trading strategy by taking long position to the corresponding sectors with positive FF5 alpha during 
expansion period and in the one month US T-bill during recession period, the strategy generates $7.12 \%$ higher mean return of the S\&P 500 benchmark and nearly 10 times higher Sharpe ratio. Our long-short strategy fares less well.

The paper is organised as follows: Section 2 describes the data and methodology, Section 3 presents the empirical findings of the study and Section 4 concludes the paper.

\section{Data and Methodology}

\subsection{Data}

We use monthly data of ten US sector portfolios obtained from Kenneth French's databank ${ }^{3}$ from January 1964 to December 2014. The Ten sectors are Consumer Non-Durables (NoDur), Consumer Durables (Durbl), Manufacturing (Manuf), Energy (Enrgy), High Technology Business Equipment (HiTec), Telecommunications (Telcm), Shops, Health (Hlth), Utilities (Utils) and Other sectors ${ }^{4}$. S\&P500 composite index data is from DataStream. US business cycle data is from $\mathrm{NBER}^{5}$.

In addition, we illustrate rotation strategies using a set of data a US sector investor is most likely to use nowadays: Select Sector SPDR ETFs. Those ETFs are not a perfect match for US Fama-French sector portfolios but we consider them a reasonable proxy that practitioners could use. By matching the industry definition of Fama-French sectors and Select Sector SPDR ETFs, we selected Consumer Discretionary (Durable), Consumer Staples (Nondurable), Energy, Health Care, Technology (HiTech) and Utilities sectors (6 sector ETFs) ${ }^{6}$ for trading illustration. The trading period is shorter than Fama-French sectors because of the availability of the data. The ETF data is obtained from DataStream and the trading period is from January 1999 to December 2014, providing 192 trading periods (months).

\footnotetext{
${ }^{3}$ http://mba.tuck.dartmouth.edu/pages/faculty/ken.french/data library.html

${ }^{4}$ Each sector is composed of several industries as follows: portfolio of Consumer Non-Durables: Food, Tobacco, Textiles, Apparel, Leather, Toys; Consumer Durables: Cars, TV's, Furniture, Household Appliances; Manufacturing: Machinery, Trucks, Planes, Chemicals, Office Furniture, Paper, Com Printing; Energy: Oil, Gas, and Coal Extraction and Products; High Technology Business Equipment: Computers, Software, and Electronic Equipment; Telecom: Telephone and Television Transmission; Shops: Wholesale, Retail, and Some Services (Laundries, Repair Shops); Health: Healthcare, Medical Equipment, and Drug; Utility and Others: Mines, Construction, Building Materials, Transport, Hotels, Bus Service, Entertainment and Finance industries. ${ }^{5}$ http://www.nber.org/cycles.html

${ }^{6}$ Correlation coefficients between Select Sector SPDR ETFs and Fama-French sector portfolio return are: 0.828764862 (Consumer Staples/ Non-Durable), 0.816122412, (Consumer Discretionary/ Durable), 0.961186564 (Energy), 0.973998282 (Technology/HiTech), 0.705727311 (Health), 0.855138977 (Utilities).
} 


\subsection{Methodology}

\subsubsection{Five-factor model alpha as a performance indicator and signal for sector rotation}

Fama and French (2015) extended their previous three-factor model to five-factor model with the argument that the new five factor model better describes the cross section of returns. They add two new factors, namely profitability (RMW) and investment (CMA) with their previous Market risk premium, Size (SMB), and Value (HML) factors:

$$
\begin{aligned}
R_{i t}-r_{f t}=\alpha_{i t} & +\beta_{i m}\left(R_{m t}-r_{f t}\right)+\beta_{i S M B} S M B_{t} \\
& +\beta_{i H M L} H M L_{t}+\beta_{i R M W} R M W_{t}+\beta_{i C M A} C M A_{t}+\varepsilon_{i t}
\end{aligned}
$$

Here $\left(R_{i t}-r_{f t}\right)$ is excess return of sector iover the risk-free rate $r_{f t}$ (proxied by one month US Treasury bill); $\left(R_{m t}-r_{f t}\right)$ is the market risk premium (excess return of the market defined as the value-weighted return of all CRSP firms incorporated in the US and listed on the NYSE, AMEX, or NASDAQ minus one month US Treasury bill); SMB is the difference between small cap and large cap firms that mimics the size risk. HML is the difference between high book-to-price and low book-to-market ratio; mimics value risk; RMW is the profitability factor which is the return spread of most profitable firms (Robust profitability) minus least profitable firms (Week profitability); CMA is the investment factor calculated as return spread of firms that invest conservatively minus aggressively. That is, RMW stands for robust minus weak profitability and CMA stands for conservative minus aggressive investment. The alpha of Fama-French five factor model $\left(\alpha_{i, t}\right)$ denotes the access return that an active portfolio manager achieves above the expected return due to market, size, value, profitability and investment risk factors.

\subsubsection{Sector Rotation Strategies and Buy-and-Hold}

We apply a sector rotation strategy using as a signal for timing our allocations the rolling window of FF5 alphas of sector portfolios. The rolling FF5 alphas are estimated for the period January 1967 to December 2014.We use the first 36 months of the sample period to estimate the first set of alphas using the FF5 model. In total, there are 576 trading months. To begin with, we devise a Long only and a Long/short strategy. Our Long-only strategy takes the long position in month $\mathrm{t}+1$ in all sector portfolios that have positive FF5 alpha for the 36 
months rolling window ending in month t. The Long-Short rotation strategy buys sector portfolios in month $t+1$ that have positive alpha in month $t$ and short-sells those with negative alpha in month $\mathrm{t}$. We rebalance the position every month using the rolling window alpha of the previous 36 months. Additionally, we incorporate economic recession and expansion periods in our trading rule. In this strategy we buy sectors with positive FF5 alpha in the expansion period, and invest in the risk-free asset (one month US T-bill) in recession periods. We compare the Sharpe ratios of trading strategies with the Buy-and-Hold strategy that represents the investment in the S\&P 500 index; a commonly used benchmark in performance evaluation literature.

\subsubsection{Transaction costs}

We report break even transaction costs in this study. Those are the maximum costs per trade (deducted from the return generated in the month in which the trade has occurred) that one could pay so that the Sharpe ratio of the strategy breaks even (i.e. equalises with) the Sharpe ratio of the buy-and-hold. Note that each strategy has a number of switches (in/out positions, so 2 switches denote one round-trip transaction) in each sector over the investment period.

\section{Empirical Findings}

\subsection{Descriptive statistics}

Descriptive statistics (Mean Excess Return, Standard Deviation, Skewness and Kurtosis) of the 10 sector portfolios over the sample period are reported in Table 1.

All the sector portfolios have highly significant leptokurtic shape. Only Durables and Health sector has positive skewness. These distribution statistics indicate the probability of extreme values in the sector returns, most of the time they are on the left tail. The mean excess returns of 10 sector portfolios are similar with a minimum monthly return of $0.45 \%$ (Utility) and a maximum monthly return of $0.69 \%$ (Health). The Utility sector portfolio exhibits the lowest standard deviation, whereas Hi-technology sector is the most risky. 
Table 1: Descriptive Statistics

This table reports the descriptive statistics (Mean, Standard Deviation, Skewness and Kurtosis) of the 10 sector portfolio returns (monthly excess returns) over the period January 1964 to December 2014. The values in the parentheses represent the p-values of Skewness-Kurtosis test for normality.

\begin{tabular}{|c|c|c|c|c|c|}
\hline \multicolumn{6}{|c|}{ Sector Portfolio Excess Returns } \\
\hline & $\begin{array}{l}\text { Mean } \\
\text { Return (\%) }\end{array}$ & Excess & $\begin{array}{l}\text { Standard } \\
\text { Deviation }\end{array}$ & $\begin{array}{l}\text { Coefficient } \\
\text { Of Skewness }\end{array}$ & $\begin{array}{l}\text { Coefficient } \\
\text { of Kurtosis }\end{array}$ \\
\hline NoDur & 0.6820 & & 4.3034 & $\begin{array}{l}-0.3161 * * * * \\
(0.0016)\end{array}$ & $\begin{array}{l}5.1108 * * * \\
(0.0000)\end{array}$ \\
\hline Durbl & 0.4561 & & 6.3366 & $\begin{array}{l}0.1592^{*} \\
(0.1058)\end{array}$ & $\begin{array}{l}7.9030 \text { *** } \\
(0.0000)\end{array}$ \\
\hline Manuf & 0.5724 & & 4.9686 & $\begin{array}{l}-0.4945 * * * \\
(0.0000)\end{array}$ & $\begin{array}{l}5.5911 * * * \\
(0.0000)\end{array}$ \\
\hline Enrgy & 0.6420 & & 5.4176 & $\begin{array}{l}-0.0081 \\
(0.9340)\end{array}$ & $\begin{array}{l}4.4112^{* * * *} \\
(0.0000)\end{array}$ \\
\hline HiTec & 0.5702 & & 6.5339 & $\begin{array}{l}-0.2251 * * \\
(0.0230)\end{array}$ & $\begin{array}{l}4.2958 * * * \\
(0.0000)\end{array}$ \\
\hline Telcm & 0.4603 & & 4.6470 & $\begin{array}{l}-0.1894 * \\
(0.0549)\end{array}$ & $\begin{array}{l}4.2634 * * * \\
(0.0000)\end{array}$ \\
\hline Shops & 0.6389 & & 5.2272 & $\begin{array}{l}-0.29187 * * * \\
(0.0035)\end{array}$ & $\begin{array}{l}5.4181 * * * \\
(0.0000)\end{array}$ \\
\hline Hith & 0.6899 & & 4.8708 & $\begin{array}{l}0.0161 \\
(0.8693)\end{array}$ & $\begin{array}{l}5.5127 * * * \\
(0.0000)\end{array}$ \\
\hline Utils & 0.4504 & & 4.0465 & $\begin{array}{l}-0.1156 \\
(0.2389)\end{array}$ & $\begin{array}{l}4.0215 * * * \\
(0.0002)\end{array}$ \\
\hline Other & 0.5382 & & 5.3302 & $\begin{array}{l}-0.4858 * * * \\
(0.0000)\end{array}$ & $\begin{array}{l}4.8271 * * * \\
(0.0000)\end{array}$ \\
\hline
\end{tabular}

$* * *$ Implies the significance at $1 \%$ level of significance.

** Implies the significance at $5 \%$ level of significance.

*Implies the significance at $10 \%$ level of significance.

\subsection{Performance of Sector Portfolios}

Table 2 reports the mean of rolling FF5 alphas ${ }^{7}$ and their standard deviations. The total number of alphas for each sector is 576 . The highest average alphas are those of the Hi Tech and Healthcare sector, while the lowest negative ones are recoded for Durables $(-24.99 \%$ p.a.). Across all 10 sectors, the average alpha is positive (3.15\% p.a.). The positive average alpha is also reported in Dellva, DeMaskey and Smith (2001) for 35 Fidelity sector funds. However, their positive alpha is the average alpha of 35 sector funds, but they didn't specify sectors with positive and negative alphas. Dou et al. (2014) use the MSCI data and report positive alpha of Energy, HiTech, and Health sectors; and negative alphas of Durable and

\footnotetext{
${ }^{7} \mathrm{We}$ have also calculated rolling alphas for the same period using FF3 model. T-test shows that with the exception of Durables and Health sector, all other FF3 and FF5 mean rolling alphas are statistically different. This indicates that the FF5 and FF3 model convey different information to investor.
} 
Manufacturing sectors both in bull market and bear market. Our findings in this paper are similar.

Table 2: Mean of Rolling FF5 Alphas

10 sector portfolios are regressed against Fama-French d 5 factors over the sample period January 1964 to December 2014 on a 36 months rolling window basis. The FF5 model is given as: $R_{i t}-r_{f t}=\propto_{i t}+\beta_{i m}\left(R_{m t}-r_{f t}\right)+\beta_{i S M B} S M B_{t}+\beta_{i H M L} H M L_{t}+\beta_{i R M W} R M W_{t}+\beta_{i C M A} C M A_{t}+\varepsilon_{i t}$ Here, Rmt (Market excess return), SMB (Small minus Big), HML (High minus Low Book-tomarket), RMW (Robust minus week profitability) and CMA (Conservative minus Aggressive investment) are the factors of Fama-French models. Alpha is the performance unexplained by exposures to the given factors. Total number of alphas estimated for each sector is 576. Table reports the annualised mean of rolling FF5 alphas and standard deviation of FF5 rolling alpha series (in percentages) for each sector.

\begin{tabular}{rrr}
\hline Sector & Mean (\%) & Std. Dev (\%) \\
\hline NoDur & -6.12 & 41.42 \\
\hline Durbl & -24.99 & 2.34 \\
\hline Manuf & -5.03 & 1.53 \\
\hline Enrgy & 6.69 & 3.06 \\
\hline HiTec & 37.21 & 2.58 \\
\hline Telcm & -11.46 & 2.32 \\
\hline Shops & 0.29 & 1.63 \\
\hline Hlth & 37.73 & 1.76 \\
\hline Utils & 6.41 & 1.90 \\
\hline Other & -9.20 & 1.27 \\
\hline
\end{tabular}

$* * *$ Implies the significance at $1 \%$ level of significance.

** Implies the significance at $5 \%$ level of significance.

*Implies the significance at $10 \%$ level of significance.

To gain some insight into the performance of sector funds over time, we plot the time series of rolling FF5 alphas of the 10 sectors over the sample period, as per Figure 1. Health sector performs well during the late 60s and 70s. During the period 1979 to 1981 energy sector provides higher alpha than any other sector, however, experienced powerful rebounds until end of 1986. We note the dominance of HiTech sector particularly during the period 1994 to 2003, which mostly coincides with the dot.com boom. We also observe that negative alphas of Energy sector are more prominent than negative alphas of the other sectors. In the case of 'Others' sector, the FF\% alpha is negative over most of the sample period.

We further perform unpaired t-test to examine whether the FF5 model alphas are different across the sectors. Table 3 reports the unpaired t-test of the rolling window FF5 alphas of 10 sector portfolios. $89 \%$ of FF5 alphas (40 out of 45 pairs) are found to be significantly different from each other at least $10 \%$ level of significance ${ }^{8}$.

\footnotetext{
839 out of 45 pairs at $5 \%$ level of significance
} 
Figure 1: FF5 Model Sector Alphas

This figure display the time series of alphas that is obtained by regressing the sector portfolios with Fama-French 5 factors separately over the sample period January 1964 to December2014 in 36 months rolling window basis.

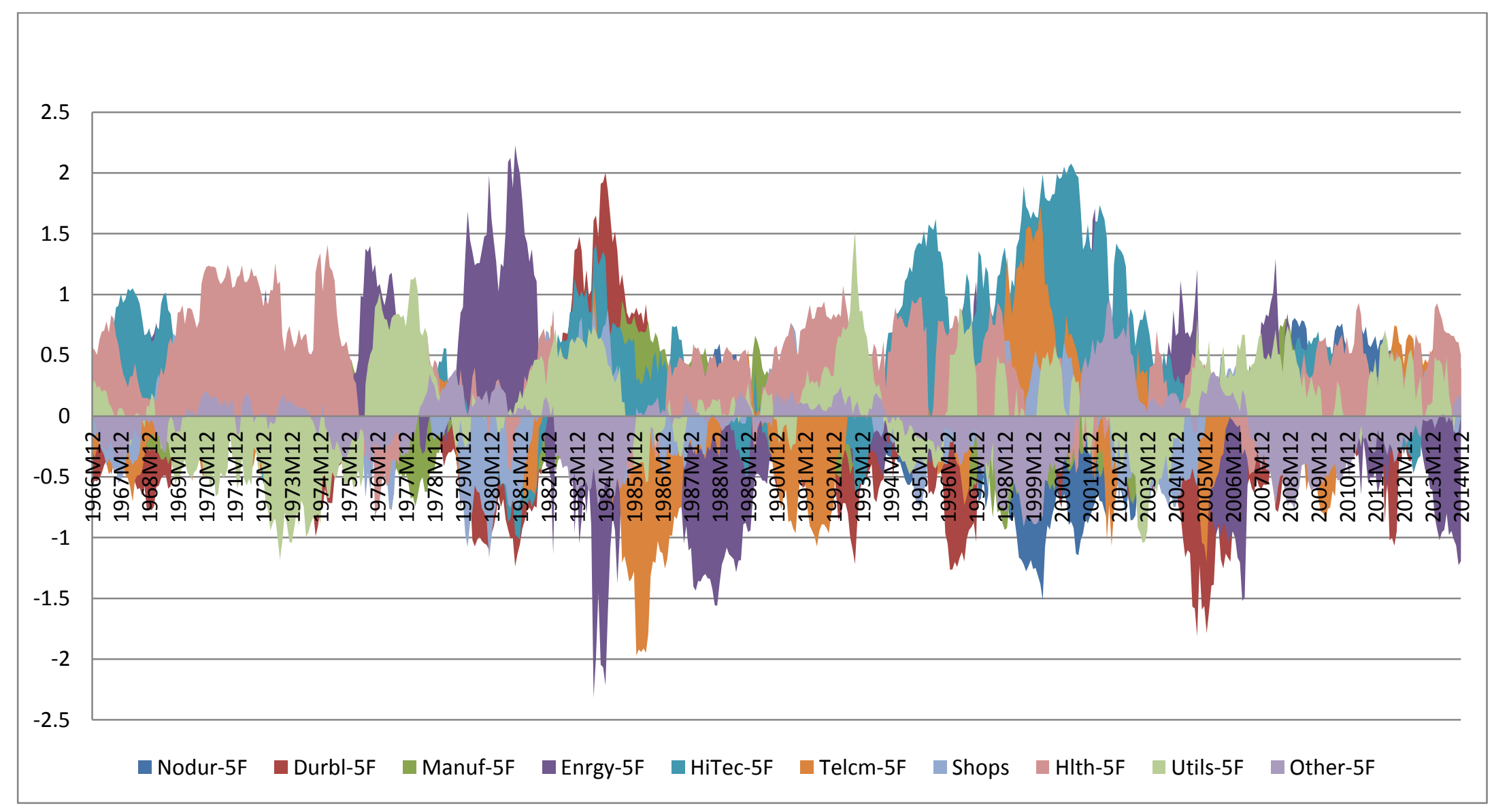


Table 3: P-value matrix of T-test for difference in Five Factor Model Alphas across pairs of sectors

T-test for the p-value of Sector Alphas in 5FM. The alphas are obtained from the rolling window regression of 10 sector portfolio with Fama-French 5 factors over the sample period January 1964 to December 2014. We perform t-test to check whether the sector alphas are different from each other.

The mean of each sector alphas are within the parentheses of 1st row and 1st column. P-value indicates level of statistical difference from each other.

\begin{tabular}{|c|c|c|c|c|c|c|c|c|c|c|}
\hline & $\begin{array}{l}\text { Nodur-5F } \\
(-0.0612)\end{array}$ & $\begin{array}{l}\text { Durbl-5F } \\
(-0.2499)\end{array}$ & $\begin{array}{l}\text { Manuf-5F } \\
(-0.0503)\end{array}$ & $\begin{array}{l}\text { Enrgy-5F } \\
(0.0669)\end{array}$ & $\begin{array}{l}\text { Hitec-5F } \\
(0.3721)\end{array}$ & $\begin{array}{l}\text { Telcm-5F } \\
(-0.1146)\end{array}$ & $\begin{array}{l}\text { Shops-5F } \\
(0.0029)\end{array}$ & $\begin{array}{l}\text { Hlth-5F } \\
(0.3773)\end{array}$ & $\begin{array}{l}\text { Utils-5F } \\
(0.0641)\end{array}$ & $\begin{array}{l}\text { Other-5F } \\
(-0.0919)\end{array}$ \\
\hline $\begin{array}{l}\text { Nodur-5F } \\
(-0.0612)\end{array}$ & - & 0.0000 & 0.6353 & 0.0003 & 0.0000 & 0.0650 & 0.0069 & 0.0000 & 0.0000 & 0.1514 \\
\hline $\begin{array}{l}\text { Durbl-5F } \\
(-0.2499)\end{array}$ & & - & 0.0000 & 0.0000 & 0.0000 & 0.0000 & 0.0000 & 0.0000 & 0.0000 & 0.0000 \\
\hline $\begin{array}{l}\text { Manuf-5F } \\
(-0.0503)\end{array}$ & & & - & 0.0006 & 0.0000 & 0.0208 & 0.0175 & 0.0000 & 0.0000 & 0.0365 \\
\hline $\begin{array}{l}\text { Enrgy-5F } \\
(0.0669)\end{array}$ & & & & - & 0.0000 & 0.0000 & 0.0650 & 0.0000 & 0.9376 & 0.0000 \\
\hline $\begin{array}{l}\text { Hitec-5F } \\
(0.3721)\end{array}$ & & & & & - & 0.0000 & 0.0000 & 0.8681 & 0.0000 & 0.0000 \\
\hline $\begin{array}{l}\text { Telcm-5F } \\
(-0.1146)\end{array}$ & & & & & & - & 0.0000 & 0.0000 & 0.0000 & 0.3928 \\
\hline $\begin{array}{l}\text { Shops-5F } \\
(0.0029)\end{array}$ & & & & & & & - & 0.0000 & 0.0145 & 0.0000 \\
\hline $\begin{array}{l}\text { Hlth-5F } \\
(0.3773)\end{array}$ & & & & & & & & - & 0.0000 & 0.0000 \\
\hline $\begin{array}{l}\text { Utils-5F } \\
(0.0641)\end{array}$ & & & & & & & & & - & 0.0000 \\
\hline $\begin{array}{l}\text { Other-5F } \\
(-0.0919)\end{array}$ & & & & & & & & & & - \\
\hline
\end{tabular}


For illustration of comparison with FF5 alphas, we include now both the FF3 and Jensen's alphas. 577 regression were completed per each portfolio and per each model, 17310 $(=577 \times 10 \times 3)$ regressions in total. Table 4 reports the percentage of statistically significant or insignificant rolling alpha estimates under the three models (CAPM, FF3 and FF5), for each sector. Manufacturing, Energy and HiTech sectors have an increasing pattern of significant alphas when we move from one factor (Jensen's alpha) to FF5 alpha. In the case of Manufacturing sector, the total significant alpha is $9.36 \%$ in case of CAPM, but it doubles when alphas are estimated by FF5. This is the sector where negative alphas increase the most - by $85 \%$. We observe similar pattern the Energy and HiTech sector. In contrast, in the Telecom sector, the percentage of total significant FF5 alphas is lower than Jensen's alphas, but higher thanFF3 alphas. This is because the telecom sector couldn't achieve many (significantly) positive alphas over the sample period, but the percentage of negative alphas in this sector has increased. This corroborates (under)performance of Telecom sector reported in Figure 1, where its time series of FF5 alpha is negative over most of the period. For Utility sector, the significant FF5 alpha is marginally lower than the FF3 one, although the percentage of positive (negative) alpha is higher (lower) than 3FM.

In summary, a significant percentage of sectors appear to have both significantly positive and significantly negative alphas in case of CAPM, 3FM and 5FM. Some of the alphas lose their significance (6 out of 10 sectors) when additional factors are included in the model. Undeniably, overall positive alpha has decreased for 9 out of 10 sector portfolios when we move from FF3 to FF5 model, while this amount is 8 out of 10 when we move from CAPM to FF5 model. If the FF5 alphas are comparatively more 'true' then their predecessors, then they should be exploitable in in the context of sector investing. We will illustrate this on the example of sector rotation strategies.

The average R-squared for each sector (also reported in Table 4) is always higher for FF5 model. This corroborates that using additional two factors in the FF5 model has enhanced the explanatory power when it comes to sector returns. 
Table 4: Significance of Alphas' over the Rolling Window

This table reports the significance of 10 sector portfolio alphas for both the three factor and five factor model at $90 \%$ confidence, based on two-tailed test. Jensen Alpha is also reported for illustration purpose. We regress the sector portfolios with one factor (market), three factors and five factors separately over 36 months rolling window (577 regression for each portfolios); and count the number of times the alphas are significant, positively significant, negatively significant, positive, or negative. The percentage of sectors with statistically significant and insignificant coefficient estimates under the models (CAPM, Fama-French $3 \mathrm{~F}$ and Fama-French $5 \mathrm{~F}$ are reported. Average R-squared for each sector portfolio and each model are reported in the last column.

\begin{tabular}{|c|c|c|c|c|c|c|c|}
\hline \multirow{2}{*}{ Sectors } & & \multicolumn{3}{|c|}{ Significant } & \multicolumn{2}{|c|}{ Overall (total) } & \multirow{2}{*}{$\begin{array}{c}\text { Average } \\
\text { R-Squared }\end{array}$} \\
\hline & & Positive & Negative & Total & Positive & Negative & \\
\hline \multirow{3}{*}{ NoDur } & Jensen Alpha & $26.34 \%$ & $0.87 \%$ & $27.21 \%$ & $74.00 \%$ & $26.00 \%$ & $71.26 \%$ \\
\hline & 3F Alpha & $20.28 \%$ & $3.81 \%$ & $24.09 \%$ & $72.62 \%$ & $27.38 \%$ & $77.81 \%$ \\
\hline & 5F Alpha & $4.68 \%$ & $5.20 \%$ & $9.88 \%$ & $46.27 \%$ & $53.73 \%$ & $82.17 \%$ \\
\hline \multirow{3}{*}{ Durbl } & Jensen Alpha & $1.04 \%$ & $10.75 \%$ & $11.79 \%$ & $37.95 \%$ & $62.05 \%$ & $67.26 \%$ \\
\hline & 3F Alpha & $3.29 \%$ & $9.71 \%$ & $13.00 \%$ & $26.86 \%$ & $73.14 \%$ & $75.56 \%$ \\
\hline & 5F Alpha & $2.60 \%$ & $9.88 \%$ & $12.48 \%$ & $23.74 \%$ & $76.26 \%$ & $78.00 \%$ \\
\hline \multirow{3}{*}{ Manuf } & Jensen Alpha & $6.76 \%$ & $2.60 \%$ & $9.36 \%$ & $50.61 \%$ & $49.39 \%$ & $87.61 \%$ \\
\hline & 3F Alpha & $6.59 \%$ & $7.45 \%$ & $14.04 \%$ & $49.22 \%$ & $50.78 \%$ & $89.83 \%$ \\
\hline & 5F Alpha & $10.57 \%$ & $8.15 \%$ & $18.72 \%$ & $36.22 \%$ & $63.78 \%$ & $91.02 \%$ \\
\hline \multirow{3}{*}{ Enrgy } & Jensen Alpha & $4.68 \%$ & $2.43 \%$ & $7.11 \%$ & $69.15 \%$ & $30.85 \%$ & $45.46 \%$ \\
\hline & 3F Alpha & $8.32 \%$ & $2.95 \%$ & $11.27 \%$ & $57.89 \%$ & $42.11 \%$ & $57.12 \%$ \\
\hline & 5F Alpha & $10.92 \%$ & $7.80 \%$ & $18.72 \%$ & $57.02 \%$ & $42.98 \%$ & $65.12 \%$ \\
\hline \multirow{3}{*}{ HiTec } & Jensen Alpha & $5.03 \%$ & $8.84 \%$ & $13.86 \%$ & $42.63 \%$ & $57.37 \%$ & $76.36 \%$ \\
\hline & 3F Alpha & $16.64 \%$ & $2.95 \%$ & $19.58 \%$ & $57.54 \%$ & $42.46 \%$ & $85.15 \%$ \\
\hline & 5F Alpha & $23.05 \%$ & $1.21 \%$ & $24.26 \%$ & $71.75 \%$ & $28.25 \%$ & $87.59 \%$ \\
\hline \multirow{3}{*}{ Telcm } & Jensen Alpha & $12.48 \%$ & $4.85 \%$ & $17.33 \%$ & $59.62 \%$ & $40.38 \%$ & $56.26 \%$ \\
\hline & 3F Alpha & $7.11 \%$ & $2.25 \%$ & $9.36 \%$ & $47.83 \%$ & $52.17 \%$ & $62.52 \%$ \\
\hline & 5F Alpha & $2.95 \%$ & $7.97 \%$ & $10.92 \%$ & $37.09 \%$ & $62.91 \%$ & $66.50 \%$ \\
\hline \multirow{3}{*}{ Shops } & Jensen Alpha & $21.66 \%$ & $5.55 \%$ & $27.21 \%$ & $58.23 \%$ & $41.77 \%$ & $73.78 \%$ \\
\hline & 3F Alpha & $13.52 \%$ & $2.25 \%$ & $15.77 \%$ & $63.08 \%$ & $36.92 \%$ & $78.87 \%$ \\
\hline & 5F Alpha & $6.93 \%$ & $2.60 \%$ & $9.53 \%$ & $50.43 \%$ & $49.57 \%$ & $82.49 \%$ \\
\hline \multirow{3}{*}{ Hlth } & Jensen Alpha & $14.73 \%$ & $1.21 \%$ & $15.94 \%$ & $67.94 \%$ & $32.06 \%$ & $61.11 \%$ \\
\hline & 3F Alpha & $21.49 \%$ & $0.00 \%$ & $21.49 \%$ & $89.25 \%$ & $10.75 \%$ & $70.21 \%$ \\
\hline & 5F Alpha & $20.45 \%$ & $0.00 \%$ & $20.45 \%$ & $77.99 \%$ & $22.01 \%$ & $73.17 \%$ \\
\hline \multirow{3}{*}{ Utils } & Jensen Alpha & $11.79 \%$ & $1.21 \%$ & $13.00 \%$ & $67.07 \%$ & $32.93 \%$ & $38.92 \%$ \\
\hline & 3F Alpha & $4.51 \%$ & $1.21 \%$ & $5.72 \%$ & $48.01 \%$ & $51.99 \%$ & $56.25 \%$ \\
\hline & 5F Alpha & $3.29 \%$ & $0.87 \%$ & $4.16 \%$ & $57.02 \%$ & $42.98 \%$ & $62.35 \%$ \\
\hline \multirow{3}{*}{ Other } & Jensen Alpha & $5.55 \%$ & $7.11 \%$ & $12.65 \%$ & $51.30 \%$ & $48.70 \%$ & $87.17 \%$ \\
\hline & 3F Alpha & $0.17 \%$ & $14.90 \%$ & $15.08 \%$ & $27.21 \%$ & $72.79 \%$ & $92.48 \%$ \\
\hline & 5F Alpha & $1.56 \%$ & $9.19 \%$ & $10.75 \%$ & $43.67 \%$ & $56.33 \%$ & $93.32 \%$ \\
\hline
\end{tabular}


From the analysis that has been done so far in this study, it is observed that the risk adjusted performance of sector portfolios in terms of one- or three-factor model is different to that of the five-factor model. The significant difference between the time series of FF3 and FF5 alphas indicates that they convey different information.

Table 5 and Table 6 report the Ordinary Least Square (OLS) estimates of three-factor model and five-factor model respectively for our ten sector portfolios for the full sample period January 1964 to December 2014. The tables report the alpha, factor betas and R-squared of the regressions. In the case of FF3 (Table 50) 50\% of sector alphas is significantly different from zero. Only two sectors (Durables \& Others) show significant underperformance after adjusting for market, size and value factors; while three sectors show significant outperformance (Non durables, Hi Tech and Health). Almost all of the betas are found to be significant.

Table 6 shows similar results. According to FF5 model alpha, Durables, Manufacturing and 'Others' significantly underperform by $0.45 \%, 0.16 \%$, and $0.23 \%$ respectively, after adjusting for market, size, value, profitability and investment risk. Similar to FF3, FF5 also shows 50\% significant non-zero sector alphas. With the exception of Non-durable sector, the alphas that are significant in FF3 remain significant in FF5model. It also can be observed that, apart from HiTec, the significant alphas in the FF5 are lower than those of FF3. This might indicate that, FF5 captures some of the unsystematic risk that FF3 cannot capture leaving less exploitable return for active managers. Moreover, the R-squared of FF5 is higher than that of FF3 for each of the ten sectors. This clearly shows a better fit of FF5 model to the sector portfolios. Hence from the statistical point of view, we can argue that, in an unconditional setting FamaFrench five-factor model is more accurate for sector pricing than their previous three factor model. However, the significant alphas indicate that, there are some returns left unexplained beyond the exposures to Market, Size, Value, Profitability, and Investment factors and that they can be exploited.

In model diagnostics, we perform redundant variables test to check the statistical significance of two addition factors (RMW and CMA) in FF5 Model. We use a Likelihood ratio test that assumes FF3 model is a nested model of FF5 model; and hypothesise that the variable of interest has zero coefficient and might thus be deleted from the equation. The test statistics of redundant variables test (F-statistic) has an exact finite sample F-distribution under null hypothesis. Panel A of Table 7 consist the results of redundant variables (Likelihood ratio) 
test under the null hypotheses: $H_{01}: \beta_{R M W}=0 ; H_{02}: \beta_{C M A}=0 ; H_{03}: \beta_{R M W}=\beta_{C M A}=0$. We can observe that, eight out of ten portfolios exhibits significant profitability beta whereas five out of ten portfolios exhibit significant investment betas. Both profitability and investment factor are jointly significant in all but one portfolio (Energy).

It is a custom to believe that aggregate shocks such as business cycles will cause a structural break in a time-series. A structural change in second moments will produce a change in asset betas that might result in a spuriously significant alpha, (Turtle and Zhang, 2015). During model diagnostics we check whether there is a structural change in the Fama-French asset pricing models due to the business cycles; with an intention to derive trading strategies accordingly. In this manner, we perform Factor Breakpoint test that splits an estimated equation's sample into a number of subsamples classified by one or more variables and examines whether there are significant differences in equations estimated in each of those subsamples. The Wald statistics in the Panel B of Table 7 indicates that, both FF3 and FF5 model exhibit structural changes due to business cycles; FF5 differing more significantly than FF3 between economic states. Given these results, we will develop a trading strategy that incorporates business cycles with a potential of generating better performance. 
Table5: Regression of 3 Factor model with 10 sector portfolios

This table reports the Ordinary Least Square estimates of 10 sector portfolios by Fama-French three factor model (3FM) over the sample period January 1664 to December 2014.The 3FM is expressed as:

$R_{i t}-r_{f t}=\propto_{i t}+\beta_{i m}\left(R_{m t}-r_{f t}\right)+\beta_{i S M B} S M B_{t}+\beta_{i H M L} H M L_{t}+\varepsilon_{i t}$

Here, Rmt (Market excess return), SMB (Small minus Big), and HML (High minus Low Book-to-market), are the factors of Fama-French models. Alpha (intercepts) is the average returns, expressed in percentage, unexplained by exposures to the Rmt, SMB, and HML. The values in the parentheses represent the p-values.

\begin{tabular}{|c|c|c|c|c|c|}
\hline $\begin{array}{l}\text { Sector } \\
\text { Portfolio } \\
\end{array}$ & Alpha & $\begin{array}{l}\text { Market } \\
\text { Beta } \\
\end{array}$ & SMB Beta & HML Beta & $\mathbf{R}^{2}$ \\
\hline NoDur & $\begin{array}{l}0.2088 * * \\
(0.031)\end{array}$ & $\begin{array}{l}0.8420 * * * \\
(0.000)\end{array}$ & $\begin{array}{l}-0.0381 \\
(0.234)\end{array}$ & $\begin{array}{l}0.1704 * * * \\
(0.000)\end{array}$ & 0.7067 \\
\hline Durbl & $\begin{array}{l}-0.3915 * * * \\
(0.006)\end{array}$ & $\begin{array}{l}1.2134 * * * \\
(0.000)\end{array}$ & $\begin{array}{l}0.1587 * * * \\
(0.001)\end{array}$ & $\begin{array}{l}0.5353 * * * \\
(0.000)\end{array}$ & 0.7071 \\
\hline Manuf & $\begin{array}{l}-0.0379 \\
(0.582)\end{array}$ & $\begin{array}{l}1.0701 * * * \\
(0.000)\end{array}$ & $\begin{array}{l}0.0285 \\
(0.2113)\end{array}$ & $\begin{array}{l}0.1808 * * * \\
(0.000)\end{array}$ & 0.8879 \\
\hline Enrgy & $\begin{array}{l}0.1453 \\
(0.374)\end{array}$ & $\begin{array}{l}0.8974 * * * \\
(0.000)\end{array}$ & $\begin{array}{l}-0.2154 * * * \\
(0.000)\end{array}$ & $\begin{array}{l}0.2975 * * * \\
(0.000)\end{array}$ & 0.4711 \\
\hline HiTec & $\begin{array}{l}0.1916^{*} \\
(0.098)\end{array}$ & $\begin{array}{l}1.0935 * * * \\
(0.000)\end{array}$ & $\begin{array}{l}0.2039 * * * \\
(0.000)\end{array}$ & $\begin{array}{l}-0.6286 * * * \\
(0.000)\end{array}$ & 0.8170 \\
\hline Telcm & $\begin{array}{l}0.0567 \\
(0.649) \\
\end{array}$ & $\begin{array}{l}0.8391 * * * \\
(0.000)\end{array}$ & $\begin{array}{l}-0.2046 * * * \\
(0.000) \\
\end{array}$ & $\begin{array}{l}0.1128 * * * \\
(0.012)\end{array}$ & 0.5811 \\
\hline Shops & $\begin{array}{l}0.0907 \\
(0.402)\end{array}$ & $\begin{array}{l}0.9880 * * * \\
(0.000)\end{array}$ & $\begin{array}{l}0.1391 * * * \\
(0.000)\end{array}$ & $\begin{array}{l}0.0363 \\
(0.348) \\
\end{array}$ & 0.7507 \\
\hline Hlth & $\begin{array}{l}0.4430 * * * \\
(0.000)\end{array}$ & $\begin{array}{l}0.8265 * * * \\
(0.000)\end{array}$ & $\begin{array}{l}-0.2404 * * * \\
(0.000)\end{array}$ & $\begin{array}{l}-0.2741 * * * \\
(0.000)\end{array}$ & 0.6273 \\
\hline Utils & $\begin{array}{l}0.0062 \\
(0.960)\end{array}$ & $\begin{array}{l}0.6550 * * * \\
(0.000)\end{array}$ & $\begin{array}{l}-0.1785 * * * \\
(0.000)\end{array}$ & $\begin{array}{l}0.4593 * * * \\
(0.000)\end{array}$ & 0.4611 \\
\hline Other & $\begin{array}{l}-0.2019 * * * \\
(0.004)\end{array}$ & $\begin{array}{l}1.1658 * * * \\
(0.000)\end{array}$ & $\begin{array}{l}0.0670 * * * \\
(0.004)\end{array}$ & $\begin{array}{l}0.3766^{* * * *} \\
(0.000)\end{array}$ & 0.9001 \\
\hline
\end{tabular}

$* * *$ Implies the significance at $1 \%$ level of significance.

** Implies the significance at $5 \%$ level of significance.

*Implies the significance at $10 \%$ level of significance. 
Table 6: Regression of 5 Factor model with 10 sector portfolios

This table reports the Ordinary Least Square estimates of 10 sector portfolios by Fama-French five factor model (5FM) over the sample period January 1964 to December 2014.The 5FM is expressed as:

$R_{i t}-r_{f t}=\propto_{i t}+\beta_{i m}\left(R_{m t}-r_{f t}\right)+\beta_{i S M B} S M B_{t}+\beta_{i H M L} H M L_{t}+\beta_{i R M W} R M W_{t}+\beta_{i C M A} C M A_{t}+\varepsilon_{i t}$

Here, Rmt (Market excess return), SMB (Small minus Big), HML (High minus Low Book-to-market), RMW (Robust minus week profitability) and CMA (Conservative minus Aggressive investment) are the factors of Fama-French models. Alpha (intercepts) is the average returns unexplained by exposures to the Rmt, SMB, HML, RMW and CMA. The values of alpha are in percentage.

The values in the parentheses represent the p-values.

\begin{tabular}{|c|c|c|c|c|c|c|c|}
\hline $\begin{array}{l}\text { Sector } \\
\text { Portfolio }\end{array}$ & Alpha & $\begin{array}{l}\text { Market } \\
\text { Beta }\end{array}$ & SMB Beta & HML Beta & $\begin{array}{l}\text { RMW } \\
\text { Beta }\end{array}$ & CMA Beta & $\mathbf{R}^{2}$ \\
\hline NoDur & $\begin{array}{l}-0.0842 \\
(0.325)\end{array}$ & $\begin{array}{l}0.9103 * * * \\
(0.000)\end{array}$ & $\begin{array}{l}0.1029 * * * \\
(0.000)\end{array}$ & $\begin{array}{l}-0.0124 \\
(0.760)\end{array}$ & $\begin{array}{l}0.6310 * * * \\
(0.00)\end{array}$ & $\begin{array}{l}0.3949 * * * \\
(0.00)\end{array}$ & 0.7860 \\
\hline Durbl & $\begin{array}{l}-0.4545^{* * * *} \\
(0.002)\end{array}$ & $\begin{array}{l}1.2245 * * * \\
(0.000)\end{array}$ & $\begin{array}{l}0.1987 * * * \\
(0.000)\end{array}$ & $\begin{array}{l}0.5239 * * * \\
(0.000)\end{array}$ & $\begin{array}{l}0.1754 * * \\
(0.016)\end{array}$ & $\begin{array}{l}0.0215 \\
(0.839)\end{array}$ & 0.7100 \\
\hline Manuf & $\begin{array}{l}-0.1643^{* *} \\
(0.014)\end{array}$ & $\begin{array}{l}1.0953 * * * \\
(0.000)\end{array}$ & $\begin{array}{l}0.1010^{* * * *} \\
(0.000)\end{array}$ & $\begin{array}{l}0.1357 * * * \\
(0.000)\end{array}$ & $\begin{array}{l}0.3203 * * * \\
(0.000)\end{array}$ & $\begin{array}{l}0.0938 * * \\
(0.051)\end{array}$ & 0.9031 \\
\hline Enrgy & $\begin{array}{l}0.0980 \\
(0.562)\end{array}$ & $\begin{array}{l}0.9155^{* * * *} \\
(0.000)\end{array}$ & $\begin{array}{l}-0.2116^{* * * *} \\
(0.000)\end{array}$ & $\begin{array}{l}0.2128 * * * \\
(0.008)\end{array}$ & $\begin{array}{l}0.0235 \\
(0.780)\end{array}$ & $\begin{array}{l}0.1887 \\
(0.122)\end{array}$ & 0.4732 \\
\hline HiTec & $\begin{array}{l}0.4224 * * * \\
(0.000)\end{array}$ & $\begin{array}{l}1.0306 * * \\
(0.000)\end{array}$ & $\begin{array}{l}0.1175 * * * \\
(0.003)\end{array}$ & $\begin{array}{l}-0.4130 * * * \\
(0.000)\end{array}$ & $\begin{array}{l}-0.3953 * * * \\
(0.000)\end{array}$ & $\begin{array}{l}-0.4736 * * * \\
(0.000)\end{array}$ & 0.8344 \\
\hline Telcm & $\begin{array}{l}0.1491 \\
(0.238)\end{array}$ & $\begin{array}{l}0.8273 * * * \\
(0.000)\end{array}$ & $\begin{array}{l}-0.2754 * * * \\
(0.000)\end{array}$ & $\begin{array}{l}.09419 \\
(0.116)\end{array}$ & $\begin{array}{l}-0.3076 * * * \\
(0.000)\end{array}$ & $\begin{array}{l}0.0484 \\
(0.596)\end{array}$ & 0.5997 \\
\hline Shops & $\begin{array}{l}-0.1080 \\
(0.291)\end{array}$ & $\begin{array}{l}1.0233 * * * \\
(0.000)\end{array}$ & $\begin{array}{l}0.2644 * * * \\
(0.000)\end{array}$ & $\begin{array}{l}-0.0018 \\
(0.970)\end{array}$ & $\begin{array}{l}0.5502 * * * \\
(0.000)\end{array}$ & $\begin{array}{l}0.0732 \\
(0.322)\end{array}$ & 0.7925 \\
\hline Hith & $\begin{array}{l}0.2533 * * \\
(0.041)\end{array}$ & $\begin{array}{l}0.8732 * * * \\
(0.000)\end{array}$ & $\begin{array}{l}-0.1558 * * * \\
(0.000)\end{array}$ & $\begin{array}{l}-0.4117 * * * \\
(0.000)\end{array}$ & $\begin{array}{l}0.3807 * * * \\
(0.000)\end{array}$ & $\begin{array}{l}0.2999 * * * \\
(0.001)\end{array}$ & 0.6508 \\
\hline Utils & $\begin{array}{l}-0.0148 \\
(0.908)\end{array}$ & $\begin{array}{l}0.6653 * * * \\
(0.000)\end{array}$ & $\begin{array}{l}-0.1828 * * * \\
(0.000)\end{array}$ & $\begin{array}{l}0.4042 * * * \\
(0.000)\end{array}$ & $\begin{array}{l}-0.0143 \\
(0.822)\end{array}$ & $\begin{array}{l}0.1233 \\
(0.181)\end{array}$ & 0.4631 \\
\hline Other & $\begin{array}{l}-0.2258 * * * \\
(0.001)\end{array}$ & $\begin{array}{l}1.1605 * * * \\
(0.000)\end{array}$ & $\begin{array}{l}0.1076^{* * * *} \\
(0.000)\end{array}$ & $\begin{array}{l}0.4463 * * * \\
(0.000)\end{array}$ & $\begin{array}{l}0.1717 * * * \\
(0.000)\end{array}$ & $\begin{array}{l}-0.1597 * * * \\
(0.002)\end{array}$ & 0.9074 \\
\hline
\end{tabular}

$* * *$ Implies the significance at $1 \%$ level of significance.

** Implies the significance at 5\% level of significance.

*Implies the significance at $10 \%$ level of significance. 
Table 7: Model Diagnostics

This table reports the Likelihood Ratio test and Wald Test for Factor Break Point for the corresponding hypothesis. We perform likelihood ratio test for the redundant variables to identify the significance of the two added factors (RMW and CMA) in the Fama-French 5FM. We also perform the Factor Break Point test to examine whether the subset of parameters differs due to the business cycles (BC). The test statistics is computed from a standard Wald test of the restriction that the coefficients on the equation parameters are the same in all subsamples. The Factor Breakpoint test splits an estimated equation's sample into a number of subsamples classified by one or more variables and examines whether there are significant differences in equations estimated in each of those subsamples. A significant difference indicates a structural change in the relationship.

The p-value of Wald test and Likelihood Ratio test indicates the probability of the insignificance of corresponding regressor.

\begin{tabular}{|c|c|c|c|c|c|c|c|c|c|c|}
\hline & NoDur & Durbl & Manuf & Enrgy & HiTec & Telcm & Shops & Hlth & Utils & Other \\
\hline \multicolumn{11}{|c|}{ Panel A: Likelihood Ratio Test for Redundant Variable } \\
\hline$H_{01}: \beta_{R M W}=0$ & $\begin{array}{l}220.0168^{* * *} \\
(0.0000)\end{array}$ & $\begin{array}{l}5.7850^{\star \star} \\
(0.0165)\end{array}$ & $\begin{array}{l}93.8751^{* * *} \\
(0.0000)\end{array}$ & $\begin{array}{l}0.0784 \\
(0.7795)\end{array}$ & $\begin{array}{l}48.3847^{\star \star *} \\
(0.0000)\end{array}$ & $\begin{array}{l}23.9610^{* * *} \\
(0.0000)\end{array}$ & $\begin{array}{l}116.9313^{* \star *} \\
(0.0000)\end{array}$ & $\begin{array}{l}38.3021^{\star \star *} \\
(0.0000)\end{array}$ & $\begin{array}{l}0.050946 \\
(0.8215)\end{array}$ & $\begin{array}{l}24.53581 \\
(0.0000)^{\star \star \star}\end{array}$ \\
\hline$H_{02}: \beta_{C M A}=0$ & $\begin{array}{l}40.8665^{\star \star *} \\
(0.0000)\end{array}$ & $\begin{array}{l}0.0413 \\
(0.8391)\end{array}$ & $\begin{array}{l}3.8220^{*} \\
(0.0510)\end{array}$ & $\begin{array}{l}2.3927 \\
(0.1204)\end{array}$ & $\begin{array}{l}32.9377^{\star * *} \\
(0.0000)\end{array}$ & $\begin{array}{l}0.2814 \\
(0.5940)\end{array}$ & $\begin{array}{l}0.9815 \\
(0.3222)\end{array}$ & $\begin{array}{l}11.2710^{\star \star *} \\
(0.0008)\end{array}$ & $\begin{array}{l}1.796862 \\
(0.1806)\end{array}$ & $\begin{array}{l}10.07030 \\
(0.0016)^{* \star *}\end{array}$ \\
\hline$H_{03}: \beta_{R M W}=\beta_{C M A}=0$ & $\begin{array}{l}112.2745^{\star \star *} \\
(0.0000)\end{array}$ & $\begin{array}{l}3.0312^{\star \star} \\
(0.0490)\end{array}$ & $\begin{array}{l}47.3725^{\star \star \star} \\
(0.0000)\end{array}$ & $\begin{array}{l}1.2130 \\
(0.2945)\end{array}$ & $\begin{array}{l}31.6660^{\star \star *} \\
(0.0000)\end{array}$ & $\begin{array}{l}14.1011^{* * *} \\
(0.0000)\end{array}$ & $\begin{array}{l}61.0811^{* * *} \\
(0.0000)\end{array}$ & $\begin{array}{l}20.4472^{* * *} \\
(0.0000)\end{array}$ & $\begin{array}{l}1.108467 \\
(0.3307)\end{array}$ & $\begin{array}{l}23.99183 \\
(0.0000)^{\star * *}\end{array}$ \\
\hline \multicolumn{11}{|c|}{ Panel B: Factor Break Point Test } \\
\hline $\begin{array}{l}\text { Structural change due to } \mathrm{BC} \\
(5 \mathrm{FM})\end{array}$ & $\begin{array}{l}7.5203 \\
(0.2754)\end{array}$ & $\begin{array}{l}5.9712 \\
(0.4264)\end{array}$ & $\begin{array}{l}9.5444 \\
(0.1452)\end{array}$ & $\begin{array}{l}36.9510^{\star \star \star *} \\
(0.0000)\end{array}$ & $\begin{array}{l}11.1681^{*} \\
(0.0833)\end{array}$ & $\begin{array}{l}8.2301 \\
(0.2217)\end{array}$ & $\begin{array}{l}23.5365^{\star \star \star} \\
(0.0000)\end{array}$ & $\begin{array}{l}9.3835 \\
(0.1531)\end{array}$ & $\begin{array}{l}25.95887 \\
(0.0002)^{\star * \star}\end{array}$ & $\begin{array}{l}9.007625 \\
(0.1731)\end{array}$ \\
\hline $\begin{array}{l}\text { Structural change due to } \mathrm{BC} \\
(3 \mathrm{FM})\end{array}$ & $\begin{array}{l}16.0655^{\star \star \star} \\
(0.0029)\end{array}$ & $\begin{array}{l}5.9624 \\
(0.2020)\end{array}$ & $\begin{array}{l}10.5225^{* *} \\
(0.0325)\end{array}$ & $\begin{array}{l}35.2219^{* * *} \\
(0.0000)\end{array}$ & $\begin{array}{l}7.8421^{*} \\
(0.0975)\end{array}$ & $\begin{array}{l}10.4302^{* *} \\
(0.0338)\end{array}$ & $\begin{array}{l}22.0615^{\star * *} \\
(0.0002)\end{array}$ & $\begin{array}{l}11.3597^{* *} \\
(0.0228)\end{array}$ & $\begin{array}{l}15.82159 \\
(0.0033)^{\star * *}\end{array}$ & $\begin{array}{l}12.72868 \\
(0.0127)^{* *}\end{array}$ \\
\hline
\end{tabular}

***Implies the significance at $1 \%$ level of significance.

** Implies the significance at $5 \%$ level of significance.

*Implies the significance at $10 \%$ level of significance. 


\subsection{Sector Rotation Strategy}

Given results from the previous section, which show better fit of the five-factor model to US sector returns, we will proceed in this section using five-factor model as a basis for our trading strategy. ${ }^{9}$ Sorensen and Burke (1986) argue that, application of a sector rotation strategy requires at least two assumptions. First, we must assume that sector-specific effects cause price movements to differ from one group to another. We have shown earlier in this paper that five-factor alphas overall differ between sectors (see Table 3). Second, sector rotation assumes that the firms within a sector exhibit some homogeneity in their relative price movements, aside from overall market influences. Intuitively, companies in the same sector or industry would exhibit higher pairwise return correlations that companies from different industries. Firms within the same industry that operate under the same regulatory environment are likely to react similarly to technological innovations, and also exhibit similar sensitivity to macroeconomic shocks and/or government policy. These firms are also likely to be exposed equally to the fluctuations in the supply \& demand or across the consumersupplier chain of their corresponding market. We hypothesised that, if the FF5 model produces true alpha then these rolling alphas can be used in sector rotation strategies.

Note that the trading strategies we use in this paper are for illustration purpose only. It is not the aim of this paper to identify the best or most optimal strategy to trade upon. We first illustrate sector rotation using Fama-French US sector portfolios, but the strategy can be replicated (relatively) cheaply by using US sector ETFs. We demonstrate replication through ETFs later in this study.

Table 8 provides the annualised returns, standard deviation, and Sharpe ratios of long-only and long-short sector rotation strategies. We observe that long-only based sector rotation trading provides nearly double the buy-and-hold return of S\&P 500 with similar standard deviation. Sharpe ratios of these strategies are also higher (nearly four times) than the Sharpe ratio of the S\&P 500. Sharpe ratio of our long-only rotation strategy is 0.13 , which is considerably higher than the Sharpe of buy and hold strategy (0.03).

Sorensen and Burke (1986) argue that, any benefits of sector rotation may depend on existing market conditions irrespective of the particular analytical approach. We test their claims by splitting the trading periods according to the NBER business cycles. Factor Breakpoint test

${ }^{9}$ Results of sector rotation strategy using the three factor model are available from the authors. 
due to business cycles (Table 7) also suggest the possibility of more accurate trading and generate higher return by incorporating business cycles in the trading strategies. The trading strategy where we buy corresponding sectors with positive FF5 alpha in the expansion period otherwise invest in risk-free asset, generates the superior returns. The returns are more than $7 \%$ higher than the buy-and-hold return of S\&P 500 with at least $2 \%$ lower risk (standard deviation). Even more pronounced than in the long-only trading, the Sharpe ratio of the longonly strategy that accounts for recession is around five times higher than that of the buy and hold of the S\&P 500 index.

Table 8: Trading with alphas

This table reports the annualised Mean return, Standard Deviation and Sharpe Ratio of long only and long-short sector rotation strategies with FF5 rolling window alphas. The buy-and-hold strategy represents the investment in the S\&P 500 index. Rotation strategies take long position in the sector portfolios that have positive alpha of 36 months rolling window regression. Another rotations strategy incorporates business cycles and take long position in the sector portfolios that have positive alpha of 36 months rolling window regression, however during recession it invests in one month US T-Bill. The Long-Short rotation strategies buy sector portfolios that have positive alpha and sell those with negative alpha. We used NBER recession index to calculate the return in recession and expansion period. Mean returns and standard deviations (Std. Dev.) have been annualised.

\begin{tabular}{l|l|l|l}
\hline & Mean Return & Std. Dev & Sharpe Ratio \\
\hline Trading with 5FM (Long Only) & $11.07 \%$ & $15.83 \%$ & 0.12462 \\
\hline Trading with 5FM (Long -Short) & $-0.52 \%$ & $4.39 \%$ & -0.3465 \\
\hline $\begin{array}{l}\text { Trading with 5FM (Long Only) } \\
\text { (Buy\& Hold risk-free in Recession) }\end{array}$ & $12.79 \%$ & $13.24 \%$ & 0.17462 \\
\hline Buy \& Hold of S\&P 500 & $5.67 \%$ & $15.51 \%$ & 0.0333 \\
\hline
\end{tabular}

The superior performance of the sector rotation strategies based on FF5 can be seen in Figure 2, which displays cumulative return of the strategies and buy and hold of the S\&P 500 index. The cumulative return of the sector rotation strategies over buy and hold grows over time. Specifically if we compare long-only trading (FF5 long) and trading that incorporates business cycles (FF5 long with risk-free), we can observe that trading strategy that invests in T-bills during recession has the 72 BPS higher return compared to the long only sector rotation that does not account for the business cycles. It also increases the Sharpe ratio from 0.12462 to 0.17426 . The outperformance of long-only sector rotation strategies confirms the findings of Sorensen and Burke (1986) and Stangl, Jacobsen and Visaltanachoti (2009) who state that, sector rotation strategy that accounts for different stages of the business cycles outperforms the market. 
Figure 2: Cumulative return of sector rotation strategies versus benchmark S\&P500

This figure displays the cumulative return of sector rotation based on FF5 alpha. The returns are compared with the buy-and-hold cumulative return of S\&P 500.

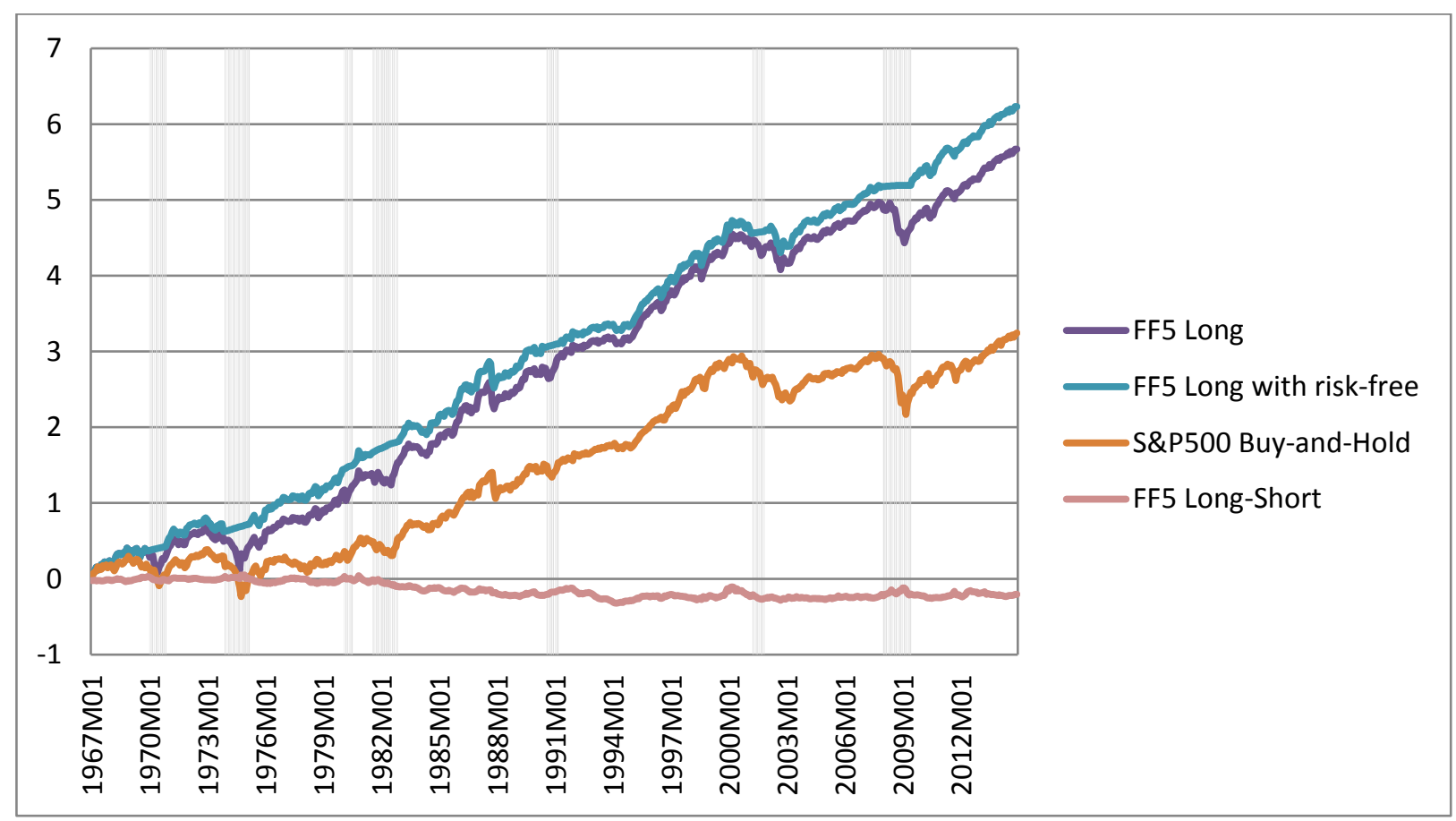

\subsection{Sector rotation with ETFs}

Fama-French sectors portfolios are not readily investable and hence our strategies would be more valuable from practitioners' point of view if tested with sector ETFs. To this end, we use six 'Select Sector SPDR ETFs' as described in Section 2 to replicate our sector rotation strategies.

Table 10 reports the mean return standard deviation, the Sharpe ratios of the strategies. We also report the maximum transaction costs that investor can afford to pay per each trade so that the Sharpe ratio of the given strategy breaks-even with the Sharpe ratio of the buy-andhold. It can be seen that ETFs trading provides lower return than trading with Fama-French sector portfolios, which could be due to different trading periods. The ETF trading period is from January 1999 to December 2014, consisting of 192 months (26 recessionary months and 166 expansionary months) compare to the 576 trading months (83 recessionary months and 493 expansionary months) of Fama-French portfolios. Note that, the S\&P 500 returns for those 192 trading months is $2.0498 \%$ compare to the $5.67 \%$ return for the 576 trading periods. Sharpe ratio of our long-only rotation strategy is four times that of the buy-and-hold 
while the Sharpe ratio of the long-only strategy with accounts for recession is nearly 10 times that of the buy and hold, making it the most successful of our three rotation strategies. The long-short strategy remains unsuccessful. This can infer some conclusions about portfolio persistence: positive alphas utilised in the long-only strategies are more likely to lead to future positive alphas, while negative alphas are not a good predictor of future negative alphas leading to poor performance of long-short strategies that utilize them.

Break-even level of transaction costs per trade for each portfolio is calculated to assess the feasibility of our strategy for investors. Break-even transaction cost is expressed in basis points and it is the maximum cost per trade that can be paid, which equalises the Sharpe ratio of our rotation strategy to that of the buy and hold benchmark. The higher the break-even transaction costs are, the more feasible our strategy is. Similar to our rotation strategies with Fama-French sector portfolios, we find that long-only strategies provide higher return than S\&P 500 benchmark whereas the long-short strategies provide lower return. The highest return is observed in the rotation strategy that takes long position in the corresponding sector ETFs during expansion period but invests in T-bill in recession period, more than $7 \%$ higher return than the benchmark. Break-even transaction cost of rotation strategy that invests Tbills during recession suggests that investors can pay anything up to 326bps per trade and still generate Sharpe ratios higher than the buy-and-hold of the S\&P 500. The breakeven costs per trade for long only sector rotation are lower (148 bps per trade) but given that ETF trading is cheap, the strategy is highly feasible for investors.

\section{Table 10: Trading with Sector ETFs}

This table reports the sector ETFs' annualised mean return, Standard Deviation, Sharpe Ratio and Break-even Transaction cost per trade of several strategies, as per Section 2.2.2. of the paper, over the trading period January 1999 to December 2014 (192 trading months: 166 expansionary periods and 26 recessionary periods). The buy-and-hold strategy represents the investment in the S\&P 500 index. We use NBER recession index to determine recession and expansion period. Mean returns and standard deviations (Std. Dev.) have been annualised.

\begin{tabular}{l|l|l|l|l}
\hline Trading Strategy & $\begin{array}{l}\text { Mean Return } \\
(\%)\end{array}$ & $\begin{array}{l}\text { Std. Dev } \\
(\%)\end{array}$ & Sharpe Ratio & Break-even TC \\
\hline Long Only based on FF5 alpha & 5.5331 & 16.2867 & 0.083911 & 147.73 BPS \\
\hline Long -Short based on FF5 alpha & 0.5168 & 7.2562 & -0.048748 & Negative \\
\hline $\begin{array}{l}\text { Long Only with risk-free asset in } \\
\text { Recession }\end{array}$ & 9.1910 & 13.7509 & 0.162814 & 326.66 BPS \\
\hline Buy \& Hold S\&P 500 & 2.0498 & 16.8809 & 0.025382 & N/A \\
\hline
\end{tabular}


One can view the outperformance of our sector trading strategies as an implication violates the efficient market hypothesis. Although the justification of efficient market hypothesis is beyond the scope of this study, we use the break-even transaction cost as an implication of limits to arbitrage. Break-even transaction cost in our study identify the extent to which our trading strategy can be arbitraged.

\section{Conclusions}

This paper contributes to the literature on US sector performance, where we measure performance by a new Fama-French (2015) five factor model. It further contributes to the scarce literature on sector rotation strategies by studying alpha-based sector rotation for the 10 US Fama-French sector portfolios. We perform sector rotation based on the rolling alphas and assess whether five factor model produces 'true' alphas that can be exploited by investors. With investors in mind, we also apply our sector rotation strategies using highly liquid S\&P Select Sector SPDR ETFs that, in terms of definition and coverage, are a close match to Fama-French sectors.

When comparing three- and five-factor models, OLS estimates suggest that FF5 explains the variability of the sector portfolio returns better than FF3, generating higher R-squared. The inclusion of two addition factors (RMW and CMA) increase the statistical significance and decrease the alpha estimate in most sectors. Likelihood Ratio test for redundant variable confirms the significance of profitability (RMW) and investment (CMA) betas. Moreover, FF3 and FF5 exhibits structural change due to business cycles, suggesting that business cycles can be incorporated for more accurate trading strategies.

Our long-only sector rotation strategy based on FF5 rolling alphas of Fama-French US sector portfolios in the period January 1967 - December 2014 generates 5.40\% higher return than the buy-and-hold of the S\&P 500 index and nearly four times higher Sharpe ratio. The outperformance increases when we take business cycles into consideration. However, we observe that the long-short strategy is not successful relative to buy and hold. Trading with S\&P Select Sector SPDR ETFs that match Fama-French portfolios in terms of definition, which are feasible investment option for all investors confirms these findings at an acceptable 
level of transaction costs. Our findings are consistent to those of Sorensen and Burke (1986) and Stangl, Jacobsen and Visaltanachoti (2009).

Given that non-normal characteristics of sector returns are reported in this study, future research could involve the use of non-linear models. In addition, it would be of interest to extend our rotation strategies to different asset classes using five-factor model. 


\section{References}

Aharoni, G., Grundy, B. and Zeng, Q. (2013) Stock Returns and the Miller Modigliani Valuation Formula: Revisiting the Fama French Analysis, Journal of Financial Economics, 110(2), pp. 347-357.

Baca, S. P., Garbe, B. L. and Weiss, R. a (2000) The Rise of Sector Effects in Major Equity Markets, Financial Analysts Journal, 56(5), pp. 34-40.

Beller, K. R., Kling, J. L. and Levinson, M. J. (1998) Are Industry Stock Returns Predictable?, Financial Analysts Journal, 54(5), pp. 42-57.

Campbell, J. Y., Hilscher, J. and Szilagyi, J. A. N. (2008) In Search of Distress Risk, Journal of Finance, 63(6), pp. 2899-2939.

Carhart, M. (1997) On Persistence of Mutual Fund Performance, Journal of Finance, 52, pp. $57-82$.

Chen, H. L., Jegadeesh, N. and Wermers, R. (2000) The Value of Active Mutual Fund Management: An Examination of the Stockholdings and Trades of Fund Managers, Journal of Financial and Quantitative Analysis, 35(3), p. 343-368.

Chen, L., Novy-Marx, R. and Zhang, L. (2011) An Alternative Three-Factor Model, SSRN Electronic Journal.

Chen, L. and Zhang, L. (2010) A Better Three-factor Model that Explains More Anomalies, Journal of Finance, 65(2), pp. 563-594.

Chong, J., and Phillips, G. M. (2015) Sector rotation with macroeconomic factors, The Journal of Wealth Management, 18(1), 54-68.

Conover, C. M., Gerald R. J., Robert R. J. and Jeffrey M. M. (2008) Sector Rotation and Monetary Conditions, The Journal of Investing, Vol.17(1), pp.34-46.

Conover, C. M., Jensen, G. R., Johnson, R. R. and Mercer, J. M. (2005) Is Fed Policy Stil Relevant for Investors?, Financial Analysts Journal, 61(1), pp. 70-79.

Cooper, M. J., Gulen, H. and Schill, M. J. (2008) Asset Growth and the Cross-Section of Stock Returns, Journal of Finance, 63(4), pp. 1609-1651. 
Daniel, K. and Titman, S. (2006) Market Reactions to Tangible and Intangible Information, Journal of Finance, 61(4), pp. 1605-1643.

Daniel, K. et al. (1997) Measuring Mutual fund Performance with Characteristic Based Benchmarks, The Journal of Finance, Vol.52(3), pp.1035-1058.

Dellva, W. L., DeMaskey, A. L. and Smith, C. a. (2001) Selectivity and Market Timing Performance of Fidelity Sector Mutual Funds, The Financial Review, 36(1), pp. 39-54.

Dou, P. Y., Gallagher, D. R., Schneider, D. and Walter, T. S. (2014) Cross-region and Crosssector Asset Allocation with Regimes, Accounting and Finance, 54, pp. 809-846.

Faff, R. (2004) A Simple Test of the Fama and French Model Using Daily Data: Australian Evidence, Applied Financial Economics, 14(2), pp. 83-92.

Fama, E. F. and French, K. R. (2015) A Five-Factor Asset Pricing Model, Journal of Financial Economics, Elsevier, 116(1), pp. 1-22.

Fama, E. F. and French, K. R. (2008) Dissecting Anomalies, Journal of Finance, 63(4), pp. $1653-1678$.

Fama, E. and French, K. (1996) Multifactor Explanations of Asset Pricing Anomalies, The Journal of Finance, 51(1), pp. 55-84.

Fama, E. F. and French, K. R. (1993) Common Risk Factors in the Returns on Stocks and Bonds, Journal of financial economics, Vol.33(1), pp.3-56.

Grauer, R. R., Hakansson, N. H. and Shen, F. C. (1990) Industry Rotation in the US Stock Market: 1934-1986 Returns on Passive, Semi-passive, and Active Strategies, Journal of Banking \& Finance, 14(2), pp. 513-538.

Kacperczyk, M., Sialm, C. and Zheng, L. U. (2005) On the Industry Concentration of Actively Managed Equity Mutual Funds, Journal of Finance, 60(4), pp. 1983-2012.

Novy-Marx, R. (2013) The Other Side of Value: The Gross Profitability Premium, Journal of Financial Economics, Elsevier, 108(1), pp. 1-28.

Pástor, L. and Stambaugh, R. F. (2002) Mutual Fund Performance and Seemingly Unrelated Assets, Journal of Financial Economics, 63(3), pp. 315-349. 
Shynkevich, A. (2013) Time-Series Momentum as an Intra- and Inter-Industry Effect: Implications for Market Efficiency, Journal of Economics and Business, Elsevier Inc., 69, pp. 64-852.

Sassetti, P. and Tani, M. (2006) Dynamic Asset Allocation Using Systematic Sector Rotation, The Journal of Wealth Management, Vol.8(4), pp.59-70.

Sorensen, E. H. and Burke, T. (1986) Portfolio Returns from Active Industry Group Rotation, Financial Analysts Journal, pp. 43-50.

Stangl, J., Jacobsen, B. and Visaltanachoti, N. (2009) Sector Rotation over Business-Cycles, Working Paper, Massey University, Department of Commerce, Auckland, New Zealand, retrieved from http://ssrn. com/abstract 999100.

Titman, S., Wei, K. C. J. and Xie, F. (2004) Capital Investment and Stock Returns, Journal of Financial \& Quantitative Analysis, 39(4), pp. 677-700.

Turtle, H. J. and Zhang, C. (2015) Structural Breaks and Portfolio Performance in Global Equity Markets, Quantitative Finance, 15(6), pp. 909-922.

Walkshäusl, C. and Lobe, S. (2014) The Alternative Three-Factor Model: An Alternative beyond US Markets?, European Financial Management, 20(1), pp. 33-70.

Wermers, R. (2000) Mutual Fund Performance: An Empirical Decomposition into StockPicking Talent, Style, Transactions Costs, and Expenses, The Journal of Finance, Vol.55(4), pp.1655-1695. 